\title{
A revision of the Mediterranean Raphitomidae (Gastropoda Conoidea), 6: on the Raphitoma corbis (Potiez et Michaud, 1838)
}

\author{
Francesco Pusateri', Riccardo Giannuzzi-Savelli ${ }^{2}$ \& Stefano Bartolini ${ }^{3}$ \\ 'Via Castellana 64, 90135 Palermo, Italy; e-mail: francesco@pusateri.it \\ ${ }^{2}$ Via Mater Dolorosa 54, 90146 Palermo, Italy; e-mail: malakos@tin.it (corresponding author) \\ ${ }^{3}$ Via E. Zacconi 16, 50137 Firenze, Italy; e-mail: stefmaria.bartolini@libero.it
}

\begin{abstract}
In this paper, the authors deal with Raphitoma corbis (Potiez et Michaud, 1838) (Gastropoda Conoidea), a poorly-known taxon differently interpreted over time, by fixing a neotype in order to stabilize the nomenclature because the type material has been lost.
\end{abstract}

KEY WORDS Mollusca; Gastropoda; Conoidea; neotype; Mediterranean Sea; Taxonomy.

Received 16.07.2018; accepted 21.08.2018; printed 30.09.2018; published online 05.10.2018

\section{INTRODUCTION}

The Raphitomidae Bellardi, 1875 are currently considered a well supported clade of the Conoidea (Bouchet et al., 2011). The superfamily Conoidea, with over 300 genera and 4,000 recognised species, but probably over 12,000 extant species (Bouchet, 1990; Tucker, 2004), represents the largest radiation of the entire phylum Mollusca. In a work on the phylogeny of the group based on a cladistic analysis of foregut morphology, Taylor et al. (1993) have highlighted the rampant homoplasy in the characters of shell and radula in conoideans. Accordingly, they have rearranged most of the conoideans into two families: Conidae, comprising Coninae and 4 subfamilies traditionally considered as "turrids", and Turridae s.s., including some of the traditional "turrids". More recently, Puillandre et al. (2008) and Bouchet et al. (2011), have provided a major update of conoidean classification based on DNA phylogeny. Although a larger taxonomic coverage would be desirable to further stabilize the molecular phylogeny, however, the position of the
Raphitomidae as a clade of the Conoidea is sufficiently supported.

The taxon Raphitomidae is based on the genus Raphitoma Bellardi, 1847 which was introduced comprising 30 fossil and Recent species (Bellardi, 1847: 85), previously classified in various genera (such as Pleurotoma Lamarck, 1799 and Clathurella Carpenter, 1857). Among the modern authors, Nordsieck (1977) listed 30 european species of Raphitomidae plus several subspecies and varieties. In the revision of the mediterranean Raphitomidae that we are currently carrying out, we estimated about 50 mediterranean species, some of which are still to be described.

\section{MATERIAL AND METHODS}

Our approach was exclusively based on shell morphology due to the almost total lack of anatomical data.

Specimens were studied from materials housed inseveral European museums and from private collections (see Abbreviations and Acronyms). Unless 
otherwise stated, the shells originated after sorting bioclastic sand samples collected between $0-80 \mathrm{~m}$ depth.

SEM images were taken by Andrea Di Giulio at the "LIME" (Interdepartmental Laboratory of Electron Microscopy - Roma Tre University). Light photographs were taken (if not otherwise stated) by Stefano Bartolini using a Canon EOS 400D digital photocamera, with standard objective $50 \mathrm{~mm}+$ adapted objectives (25 and $12.5 \mathrm{~mm}$ ) for a 16 and $8 \mathrm{~mm}$ vintage cine camera and by Riccardo Giannuzzi Savelli using a Canon EOS 45D mounted on a Kyowa binocular microscope, assembled with Helicon Focus 6 software and background removed with Clipping Magic.

ABBREVIATIONS AND ACRONYMS. HUJ: Hebrew University of Jerusalem (Israel); MCZR: Museo Civico di Zoologia (Roma, Italy); SMNH: Swedish Museum of Natural History (Stockholm, Sweden); CRO: Paolo Crovato (Napoli, Italy); MAR: Alessandro Margelli (S. Maria a Monte, Italy); MON: Giuseppe Monti (Brisighella, Italy); NOF: Italo Nofroni (Roma, Italy); OCC: Rosario Occhipinti (Ragusa, Italy); PAG: Attilio Pagli (Vinci, Italy); PAO: Paolo Paolini (Livorno, Italy); PAL: Alberto Palmeri (Palermo, Italy); PEN: Anselmo Peñas (Vilanova i la Geltrù, Spain); PIS: Michele Pisanu (Quartu S. Elena, Italy); PUS: Francesco Pusateri (Palermo, Italy); RUF: Stefano Rufini (Anguillara, Italy); RUG: Ruggero Ruggeri $\dagger$ (Roma, Italy); SER: Gabriele Sercia (Palermo, Italy); SOS: Maurizio Sossu (Genova, Italy); d: diameter; h: height; sh: shell/s; Std: standard deviation (DS); w: widht.

\section{RESULTS}

\section{Systematics}

Citation of unpublished names is not intended for taxonomic purposes.

Classis GASTROPODA Cuvier, 1795 Subclassis CAENOGASTROPODA Cox, 1960 Ordo NEOGASTROPODAWenz, 1938 Superfamilia CONOIDEA Fleming, 1822 Familia RAPHITOMIDAE Bellardi, 1875 Genus Raphitoma Bellardi, 1847

TYPE SPECIES. Pleurotoma hystrix Cristofori et Jan, 1832 (nomen nudum, validated by Bellardi,
1847 as "Pleurotoma histrix Jan.") by subsequent designation (Monterosato, 1872: 54).

Raphitoma corbis (Potiez et Michaud, 1838) [Pleurotoma $]$ Figs. 1, 2; 4-22

Pleurotoma corbis Potiez et Michaud, 1838: 444 (sp. 8)

Pleurotoma corbis Desmoulins, 1842: 63 ( as synonym of Pleurotoma purpurea)

Pleurotoma corbis Reeve, 1843, pl. 16 sp. 136 ( as synonym of Pleurotoma purpurea)

Pleurotoma corbis Potiez, 1844: 52, pl. 35 figs. 1,2

Pleurotoma corbis Bellardi,1847: 87 (as synonym of Pleurotoma purpurea)

Pleurotoma corbis Jay, 1850: 325 ( as synonym of Pleurotoma purpurea)

Pleurotoma corbis var. atra Monterosato, 1878: 106 (nomen nudum)

Pleurotoma corbis var. cinerea Monterosato, 1878: 106 (nomen nudum)

Pleurotoma corbis var. nebulosa Monterosato, 1878: 106 (nomen nudum)

Pleurotoma corbis var. flavida Monterosato, 1878: 106 (nomen nudum)

Pleurotoma corbis var. major Monterosato, 1878: 106 (nomen nudum)

Pleurotoma corbis var. minor Monterosato, 1878: 106 (nomen nudum)

Pleurotoma corbis var. textilis Monterosato, 1878: 106 (nomen nudum)

Pleurotoma corbis B.D.D, 1883: 91 (as synonym of Pleurotoma laviae)

Pleurotoma corbis Tryon, 1884: 335 ( as synonym of Pleurotoma purpurea)

Clathurella corbis Locard, 1886: 114

Clathurella corbis Locard, 1891a: 6

Clathurella corbis Locard, 1891b: 106

Clathurella corbiformis Locard, 1892: 65 (emendatio invalida)

Pleurotoma corbis Carus, 1893: 425 ( as synonym of Pleurotoma purpurea)

Philbertia corbiformis Nordsieck, 1968: 177 (As synonym of Philbertia densa)

Raphitoma (Philbertia) corbis Nordsieck, 1977: 57, pl.18 fig. 143

ORIGINAL DESCRIPTION. Pleurotoma corbis Potiez, 1838. Gal. Moll. Douai 1: 444, sp. 8. La Méditerranée. Potiez, 1844, Gal. Moll. Douai, Atlas (1844) p. 52, pl. 35, figs. 1, 2. 


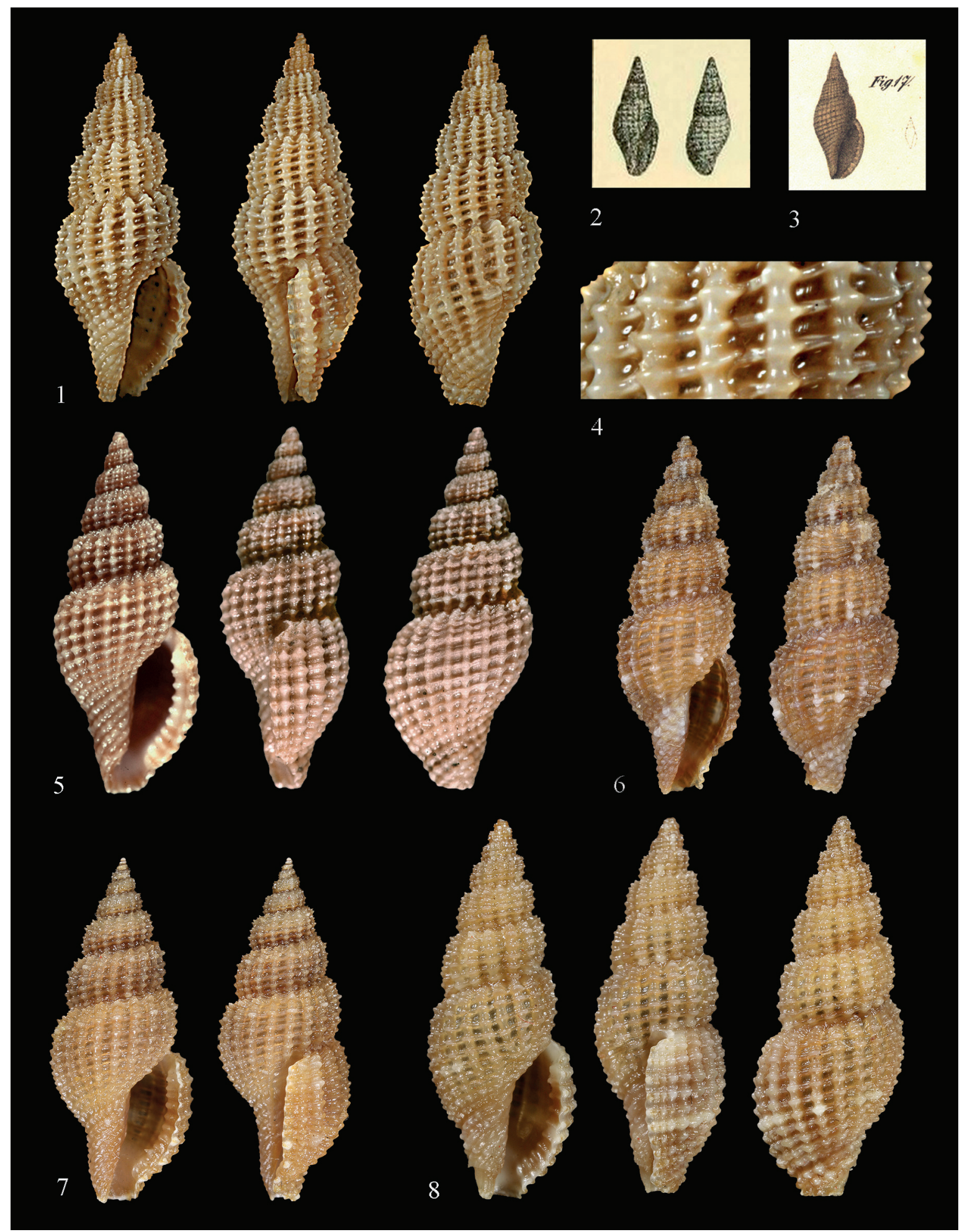

Figures 1-8. Shells of Raphitoma corbis (Potiez, 1838). Fig. 1: Neotype, Palermo, Italy (MCZR-M-16806), h: 11.6 mm; Fig. 2: original drawing by Potiez (1838); Fig. 3: original drawing by Philippi (1844) of Raphitoma laviae; Fig. 4: Neotype, details of the sculpture. Fig. 5: Roussillon (France), h: $12.3 \mathrm{~mm}$ (MNHN, labelled by Locard as P. atropurpurea; Fig. 6: Isola delle Femmine (Italy), h: 12.1 (slender form); Fig. 7: Golfo di Termini Imerese (Italy), h: 9.1 (broad form); Fig. 8: Isola delle Femmine (Italy), h: $9.4 \mathrm{~mm}$ (with 22 axial ribs). 
Potiez, 1838: "Pleur. Testa fusiformi, fulva, longitudinaliter costata, transversimque regulariter sulcata; sulcis transversis longitudinalibusque decussata; anfractibus gradatis, parte superiore angulatis; sutura profunda; apertura elongata; cauda longiuscula, extus sulcata, nodis laevibus cincta; columella valde arcuata. Longuer... 4-5 mil diametre dernière tour 1-1,5 mil. La Méditerranée".

TYPE MATERIAL. Neotype is here designed from MCZR-M-16806 labelled "Ph. atropurpurea" Figs. $1,4)$.

TYPE LOCALITY. Palermo (1886).

EXAMINATED MATERIAL. The type material and the following one: Spain. Alboran, 3 sh (PEN); Costas Mijas (Malaga), 4 sh (PEN); Begur (Girona), 1 sh (PEN); Cabo de Palos, -30 m, 1 sh (PUS).

France. St. Raphael, 1 sh (PUS).

France, Corse. Bastia, 2 sh (PUS).

Italy. Capo Pino (Sanremo), 1 sh (RUF); Riva Trigoso (Genova), 1 sh (SOS); Baratti (Livorno), 2 sh (PAO); 1 sh (NOF); Livorno, 1 sh (MON); Castiglioncello (Livorno), 1 sh (MAR), 1 sh (PAO); Punta Ala, 2 sh (PAG); Capraia Island, 1 sh. (PAG); Santa Marinella (Roma), 1 sh (RUG); Nettuno (Roma), 1 sh (OCC); Terracina (Latina), 1 sh (PAG); Civitavecchia, 1 sh (RUF); Napoli, 2 sh (PUS); Puolo (Napoli), 2 sh (RUF); Procida Island, $1 \mathrm{sh}$ (PAL); Punta Pioppeto (Procida Isl.) -6 m, 1 sh (CRO); Ponza Island -35 m, 1 sh (PAG).

Sardinia. Poetto (Cagliari), 1 sh (PIS).

Sicily. Palermo, 7 sh (PUS), 12 sh (HUJ coll. Coen lot 8079, sub nomine Philbertia purpurea; Golfo di Palermo, 13 sh (PUS); Isola delle Femmine (Palermo), 3 sh (PUS), 5 sh (SER); S. Vito Lo Capo (Trapani), 7 sh (PUS); Isola Lachea (Acitrezza, Catania), 9 sh (SMNH, lot 73197D).

DESCRIPTION. In square brackets the data of the neotype. Shell fusiform-acute, of medium size for the genus, height $8-12 \mathrm{~mm}$, mean 9.75 (DS: 1.10) [11.6], width 3.4-4.5 mm, mean 3.94, DS: 0.32 [4.3], h/d: 2.18-2.88 (mean 2.47), DS 0.15 [2.68].

Protoconch multispiral of 2.4 convex whorls, heigth $395 \mu \mathrm{m}$, width $347 \mu \mathrm{m}$, protoconch I of 1 whorls, width $164 \mu \mathrm{m}$, covered by thin cancellations, protoconch II with a diagonally cancellate sculpture starting after a short zone under the suture with fine curved axial threads. The last whorl with very short and weak keel before the onset of the teleoconch. Protoconch-teleoconch boundary strongly flexuose, opisthocline.

Teleoconch of 6-8, mean 7 [7.5], slightly convex whorls and scaled, thin, suture incised, sculpture prominent. No microgranules in the surface. Axial sculpture of 14-22 mean 18.2, Std: 1.86 [19] slightly opisthocline, equidistant ribs, and interspaces larger than the ribs. The ribs are more evident than the cordlets.

Spiral sculpture 6-7 [7] cordlets above the aperture. Sometime one or two additional weak cordlets can be present next the suture. Cancellation rectangular, with strong and elongated tubercles at the intersection of axials and spirals. Subsutural ramp narrow.

Columella simple, slightly sinuous anteriorly, gently angled posteriorly. The siphonal channel is short and wide at the end. Outer lip with 9-14 strong inner plicate denticles, mean 10.8 [10]. Sometime the last denticle can be double. Siphonal fasciole with 7-9, mean 8 , strong nodulose cords [9]. Colour from firm brown to light hazel, rarely even some costae are equally clear. Sometime in the last whorl there is a lighter cordlet on the suture.

Soft parts: unknown.

Distribution. West and Central Mediterranean.

Comparative NOTES. Specimens of light-colored R. atropurpurea (Locard et Caziot, 1900) (see Pusateri et al., 2017: 174 Fig. 8A) may be confused with $R$. corbis with light suture cordlet (see Fig. 6), but $R$. atropurpurea is distinguished by a less acute and scalar profile, to be more robust, and to the lower number of nodulose cords on the siphonal fasciole (Fig. 23).

Raphitoma corbis can be confused with specimens of light color of $R$. laviae (Philippi, 1846), but it is distinguished by its larger size, by the more acute and scalar profile and by its elongated tubercles (Fig. 24).

It also differs from $R$. lineolata (Bucquoy, Dautzenberg et Dollfuss, 1883) for the more acute profile, lower $\mathrm{h} / \mathrm{w}$ ratio (2.47 vs 2.67 ), the lower transparency inside the mouth and the almost total lack of whitish blotches (Fig. 25).

Moreover, R. densa (Monterosato, 1884) differs due to the constant presence of ash blotches missing in $R$. corbis (Fig. 26). 


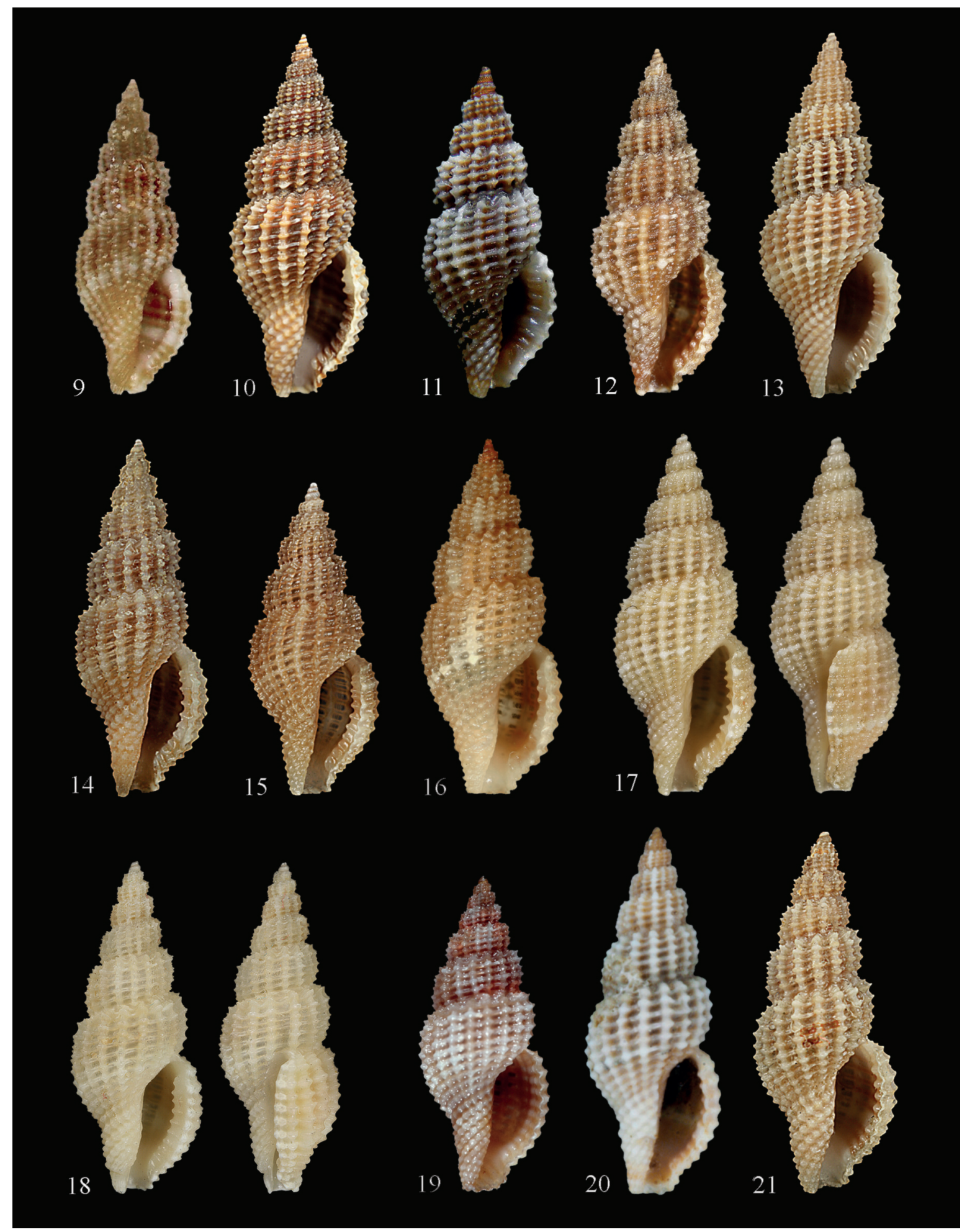

Figures 9-21. Shells of Raphitoma corbis (Potiez, 1838). Fig. 9: Civitavecchia (Italy), h: 7.9 mm (with 15 axial ribs); Fig. 10: Boozcada Is. (Turkey), h: $11.8 \mathrm{~mm}$; Fig. 11: Bay of Carini (Italy), h: $8.7 \mathrm{~mm}$; Fig. 12: Isola delle Femmine (Italy), h: $9.3 \mathrm{~mm}$; Fig. 13: Isola d'Elba (Italy), h: 11.7; Fig. 14: Secca Murelle -50 m, Montalto di Castro (Italy), h: 10 mm; Fig. 15: Tuscan Archipelago (Italy), h: 6.5 mm; Fig. 16: Gulf of Termini Imerese (Italy), h: 10.3 mm; Fig. 17: Isola delle Femmine (Italy), h: 10.5; Fig. 18: Gulf of Termini Imerese, h: 8.7 mm; Fig. 19: Tuscan Archipelago, h: 8 mm; Fig. 20: Palermo (MCZR-M-16806), h: 12.2 mm; Fig. 21: Capo Linaro, h: 11.5. 
REMARKS. The opinions of various authors on the interpretation of this species are very discordant. Especially since the types were lost during the bombing of 11 August 1944 along with all the naturalistic collections preserved at the Musée de Douai.

Moreover, the collection Michaud (still alive) was in part donated to the Musée of Lyon (now Musée des Confluences), in part passed to the city of Brive by Michaud's son Elysée, and in part was bought by Locard (Locard, 1891: 7). Only the Lyon material remains identifiable (Boyer \& Audibert, 2007), but there are no trace of $P$. corbis (Audibert pers. com.), the part in Brive having been lost, and the part in Locard's collection having lost the original labels.

The original description of Potiez \& Michaud (1838) is suitable for at least 4 or 5 different species of Raphitoma.

Monterosato (1872: 51) considers it a variety of R. purpurea, but, subsequently (Monterosato, 1878: 106) begins to doubt that it may be a variety of purpurea (?) and advances the hypothesis that it may instead be $R$. laviae Philippi, 1844.

Still Monterosato (1880: 229) confirms this synonymy, but seems somewhat hesitant since it does not assign priority to corbis Potiez \& Michaud, 1838 on laviae Philippi, 1844.
Petit (1869: 154) consider $R$. corbis a young form of Defrancia purpurea.

Monterosato (1881) refers to the quotation from Dautzenberg (1882) and assigns the species to the genus Homotoma Bellardi, 1875, pointing out that R. purpurea "manca al Mediterraneo [is missing from the Mediterranean]".

After this date, Monterosato no longer report the corbis nor the sustained synonymy with laviae. It is possible that he was misled by the original figures of Potiez (1838) and Philippi (1844) that somehow seem quite similar and the size of the two species (4-5 $\mathrm{mm}$ given by Potiez and $5.5 \mathrm{~mm}$ given by Philippi).

B.D.D. (1882: 91) consider $R$. corbis synonymous with $R$. laviae (in turn considered to be the form of $R$. purpurea) erroneously referring to $R$. $o b$ longa (Jeffreys, 1867). About $R$. oblonga (Jeffreys, 1867) see Giannuzzi-Savelli et al. (2018: 15).

Locard (1891a: 6) reports having had in his hands the original type kept at the Galerie de Douai and states that it is precisely identical to the specimen depicted by B.D.D. (1882, figs. 14, 15). He provides, for the species, a height range between 12 and $14 \mathrm{~mm}$ which is very different from that provided by Potiez (1838) in the original description (4-5 mm). Conversely, in the caption of the plate 35 n. 1 published in the volume of the Atlas

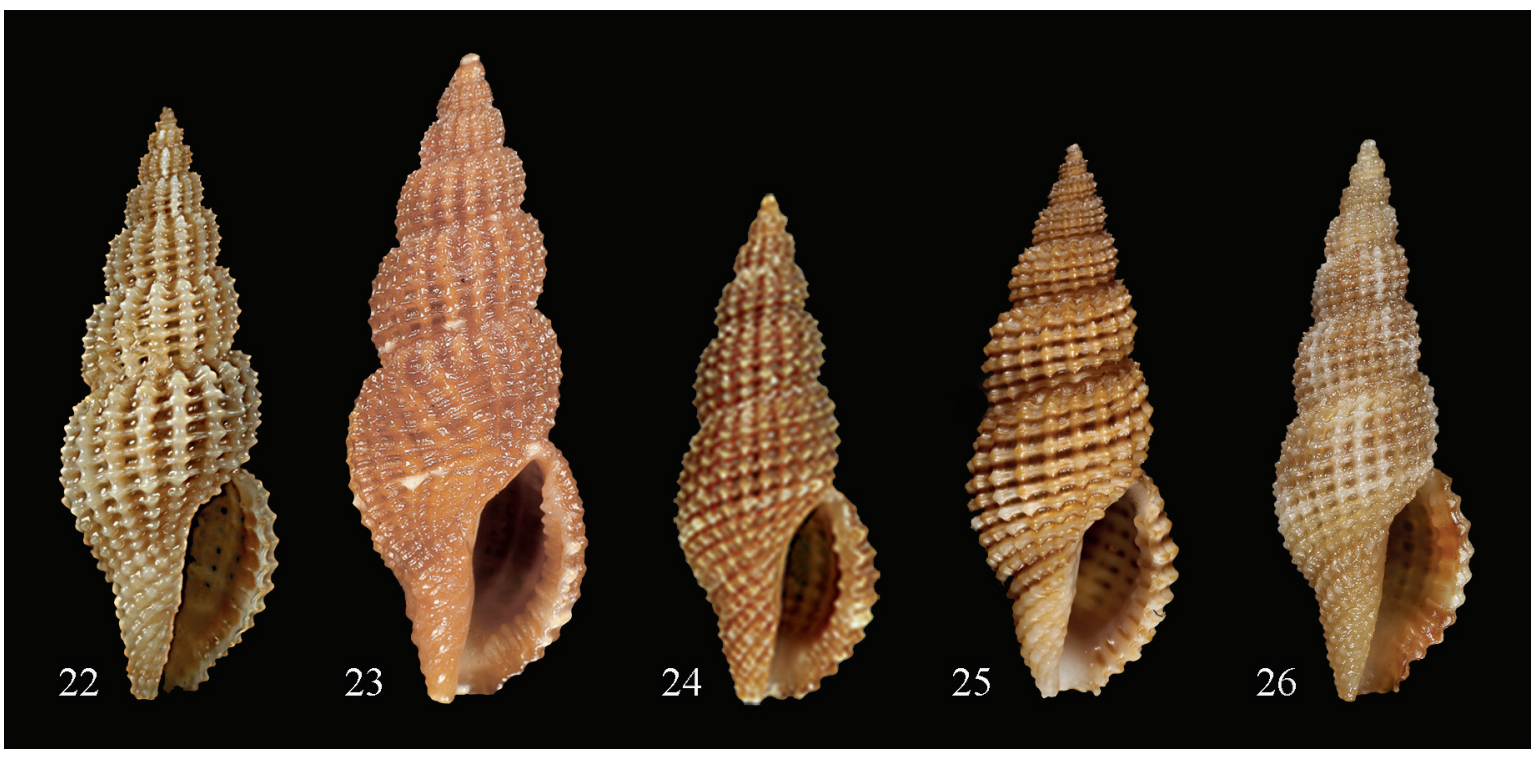

Figures 22-26. Fig. 22: Raphitoma corbis, Neotype, Palermo, Italy (MCZR-M-16806), h: 11.6 mm; Fig. 23: R. atropurpurea (Locard et Caziot, 1900), Napoli (Italy), h: 14.6 mm; Fig. 24: R. laviae (Philippi, 1846), Genova (Italy), h: 9 mm; Fig. 25 : R. lineolata (B.D.D., 1882), St. Raphael (France), h: 9.2 mm; Fig. 26: R. densa (Monterosato, 1884), Palermo, h: 10.5 mm. 


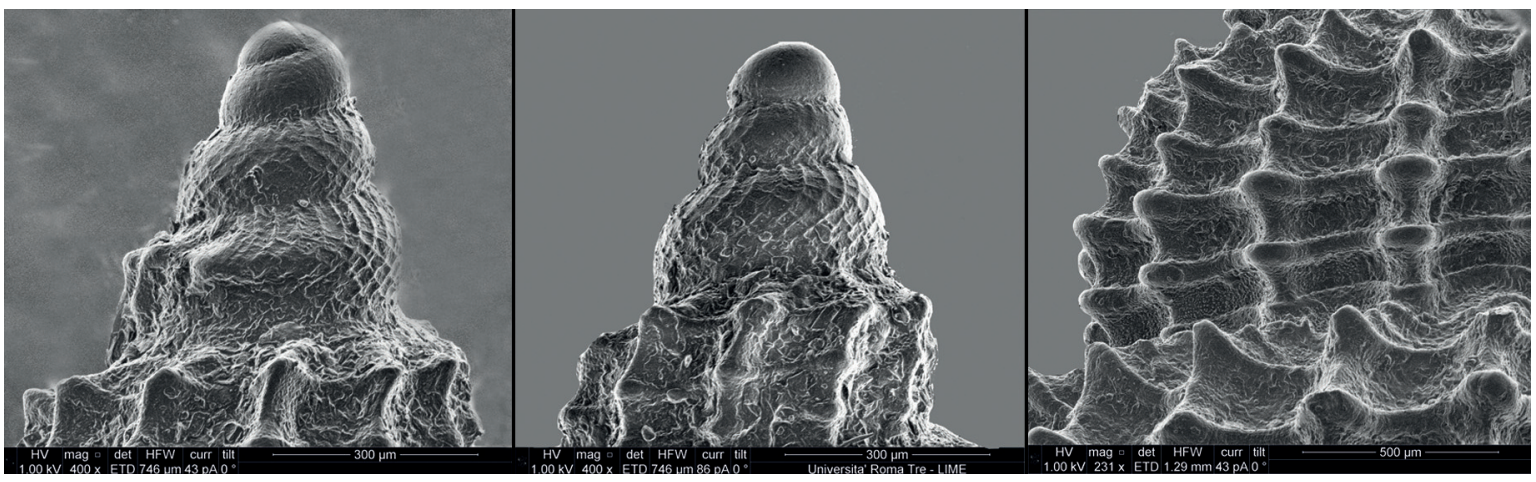

Figure 27. Raphitoma corbis. Protoconch and detail of first teoloconch whorl of a specimen from Gulf of Palermo (Italy).

(Potiez, 1844), this author indicates that the illustration is "grandeur naturelle [life-size]", or about $12 \mathrm{~mm}$. It is obvious that the measures he gave in the original description (Potiez, 1838) are completely wrong, perhaps due to a printing error.

Locard (1891b: 132) specifies that the specimen examined by him is incomplete but absolutely referable to the Clathurella contigua Monterosato, 1884, referring to fig. 15 of B.D.D. (1882) and assumed by Monterosato (1884), for indication, among the types of its $R$. contigua. For a complete treatment of the problem, see Pusateri \& Giannuzzi-Savelli (2012), which gave a final arrangemet to $R$. contigua. They fix a lectotype chosen from the original material of the author and illustrating the same sample used by B.D.D. (1882) for their figure 15 (Pusateri \& Giannuzzi-Savelli, 2012) which is found to be a typical $R$. atropurpurea of about $12 \mathrm{~mm}$.

Locard's (1891b) assumption is rather strange that, subsequently, in describing with Caziot (Locard \& Caziot, 1889 the $R$. atropurpurea makes no reference to the figure 15 of B.D.D (1882). This suggests that Locard (1891b) trusted the rather confusing photograph and did not check the original material used by Dautzenberg for "Les mollusques du Roussillon" (B.D.D., 1882). This material between 1975 and 1980 has now merged into the MNHN collections (V. Heros pers. comm.).

On the basis of these statements by Locard (1891b), we checked in his collection at MNHN all the material relating to Clathurella corbiformis (Locard had the habit to adjective the nouns and then renaming the species thus creating a plethora of invalid emendationes). We have thus found 7 lots from Saint-Raphaël, Toulon, Paulilles, Marseille, Roussillon, Saint Tropez, and Porto Pollo. To our surprise, this material, in a poor state of preservation, turns out to be a mélange of different species: $R$. densa, $R$. atropurpurea, R. philberti (Michaud, 1829), R. spadiana Pusateri et Giannuzzi-Savelli, 2012 , and the only $R$. corbis present in this material (Roussillon) is labeled as "atropurpurea".

This is a further proof of the fickleness of Locard's identifications

In conclusion, for the objective difficulties of determination (see COMPARATIVE NOTES) and a complex nomenclatural history, we consider it appropriate, even for the purpose of maintaining the nomenclatural stability, to designate a neotype.

Consequently (art. 75.3 ICZN, 1985), we have chosen a sample of the Monterosato MCZR-M16806 collection marked with two labels: " $P h$. atropurpurea" and "Palermo, 1886".

\section{ACKNOWLEDGMENTS}

The following colleagues are heartily thanked for their help with the museum samples under their care: H. Mienis (HUJ, Jerusalem); B. Cignini and M. Appolloni (MCZR, Roma, Italy); A. Warén (Swedish Museum of Natural History, Stockholm, Sweden). We also wish to thank the following friends for helping with samples from their collections, bibliography, photographs, and ecological data: Cedric Audibert (Lyon, France); Paolo Crovato (Napoli, Italy); Andrea Di Giulio (Roma, Italy); Virginie Héros (Paris, France); Alessandro Margelli (S. Maria a Monte, Italy); Giuseppe Monti (Brisighella, Italy); Italo Nofroni (Roma, Italy); Rosario Occhipinti (Ragusa, Italy); Marco Oliverio (Roma, Italy); Attilio Pagli (Vinci, Italy); Paolo 
Paolini (Livorno, Italy); Anselmo Peñas (Vilanova i la Geltrù, Spain); Michele Pisanu (Quartu S. Elena, Italy); Stefano Rufini (Anguillara, Italy); Ruggero Ruggeri $\dagger$ (Roma, Italy); Gabriele Sercia (Palermo, Italy); Carlo Smriglio (Roma, Italy), Maurizio Sossu (Genova, Italy).

\section{REFERENCES}

Bellardi L., 1847. Monografia delle Pleurotome fossili del Piemonte. Memorie della Reale Accademia delle Scienze di Torino, serie 2, 9: 531-650, 4 pls. [R. Janssen, 1993, said that the journal issue was published in 1848 but that a separate was distributed in 1847; the title and pagination for the separate is: Monografia delle Pleurotome Fossili del Piemonte. Torino, 119 pp.].

Boyer F. \& Audibert C., 2007. Le matériel d'auteur conservé au Museum de Lyon pour les taxa de Michaud, 1828 et 1829. Cahiers scientifiques du Department du Rhône, Musée des Confluences, Lyon, 13: 149-159.

Bouchet P., 1990. Turrid genera and mode of development: the use and abuse of protoconch morphology. Malacologia, 32: 69-77.

Bouchet P., Kantor Y.I., Sysoev A. \& Puillandre N., 2011. A new operational classification of the Conoidea. Journal of Molluscan Studies, 77: 273-308.

Bucquoy E., Dautzenberg P. \& Dollfuss G., 1882. Les mollusques marins de Roussillon. Tome premier: Gastropodes avec atlas de 66 planches. Paris: J.-B. Baillière \& Fils. 570 pp., 66 pls. [Turrids are in fascicule 1 (3): 85-135, pls. 11-15]. August, 1882.

Carus J.V., 1893. Prodromus Faunae Mediterraneae sive Descriptio Animalium Maris Mediterranei Incolarum quam Comparata Silva rerum Quatenus Innotuit Adiectis Locis et Nominibus Vulgaribus. Vol. II. Brachiostomata. Mollusca. Tunicata. Vertebrata. E. Schweizerbart'sche, Stuttgart, ix +854 pp.

Desmoulins C., 1842. Revision de quelques espèces de Pleurotomes. Actes de la Société Linnéenne de Bordeaux 12: 109-181.

Giannuzzi-Savelli R., Pusateri F. \& Bartolini S., 2018. A revision of the Mediterranean Raphitomidae (Gastropoda, Conoidea) 5: loss of planktotrophy and pairs of species, with the description of four new species. Bollettino Malacologico, 54 (Suppl.): 1-77.

Jay J.C., 1850. A catalogue of the shells, arranged according to the Lamarckian System, with their authorities, synonymes, and references to works where figured or described, contained in the collection of John C. Jay M.D., edition 4. New York, R. Craighead. 459 pp. [Contains a useful bibliography to early malacological publications.].
I.C.Z.N. (International Commission on Zoological Nomenclature), 1985. Internatiional Code of Zoological Nomenclature. Third Edition. The International Trust for Zoological Nomenclature, London, $\mathrm{xx}+338 \mathrm{pp}$.

Locard A., 1886. Prodrome de malacologie Française. Catalogue général des Mollusques vivants de FranceMollusques marins. Lyon, Henri Georg and Paris, J.B. Baillière et Fils. $\mathrm{x}+778$ pp.

Locard A., 1891a. Sur les Pleurotomidae vivants du group du Clathurella purpurea. L'Echange, revue Linnéenne, 7: 5-6.

Locard A., 1891b. Les coquilles marines vivantes de la faune française décrite par G. Michaud, études critiques aprés les types de ses collections. Annales de la Société d'Agriculture, Histoire Naturelle et Arts utiles de Lyon. (6) 3 [1890]: 93-134

Locard A. 1892. Les coquilles marines des côtes de France. Annales de la Société Linnéenne de Lyon 37: 1-385, 348 figs. (1891) [Also published as a separate in 1892]

Locard A. \& Caziot E., 1899. Les coquilles marines des côtes de Corse. Annales de la Société Linnéenne, Lyon, 46: 193-274. The pages 193-274 was published in 1899. [A reprint of this work was published as separate book with the same title in 1900 by J.B. Baillière et fils, Paris].

Monterosato M. di, 1872. Notizie Intorno alle Conchiglie Mediterranee. Michele Amenta, Palermo, 61 pp. [Published October 5].

Monterosato M. di, 1878a. Enumerazione e sinonimia delle conchiglie mediterranee. Giornale Scienze Naturali ed Economiche di Palermo 13: 61-115.

Monterosato M. di, 1880. Notizie intorno ad alcune conchiglie della costa d'Africa. Bullettino della Società Malacologica Italiana, 5: 213-233.

Monterosato M. di, 1884. Nomenclatura generica e specifica di alcune conchiglie mediterranee. Palermo, Stabilimento Tipografico Virzì, $152 \mathrm{pp}$.

Nordsieck F., 1968. Die Europäischen Meeres-Gehäuseschnecken (Prosobranchia) vom Eismeer bis Kapverden und Mittelmeer. Gustav Fischer, Stuttgart, viii +273 pp., 33 pls.

Nordsieck F., 1977. The Turridae of the European Seas. Roma, Ed. La Piramide, pp. 131, 26 pls.

Petit de la Saussaye S., 1869. Catalogue des mollusques testacées des mers d'Europe. Paris: F. Savy, 312 pp.

Philippi R.A., 1844. Enumeratio Molluscorum Siciliae cum viventium tum in tellure tertiaria fossilium quae in itinere suo observavit auctor. Volumen secundum continens addenda et emendanda, nec non comparationem faunae recentis siciliae cum faunis aliarum terrarum et cum fauna periodi tertiariae. Halis Saxonum, E. Anton. iv + 303 pp., pls. 13-28.

Potiez V.L.V. \& Michaud A.L.G, 1838. Galerie des mollusques, ou catalogue méthodique, descriptif et raisonné des mollusques et coquilles du Muséum de 
Douai. Paris, J.-B. Bailliére. Tome Premier. IXXXVI, 560 pp. [I-IV, errata]. [The first issue of the Atlas, likely published in 1838 , contained 56 pp., and pls. I-XXXVII; dates printed on the individual plates are I-XV, 1835; XVI-XXXIII, 1836; XXXIVXXXVII, 1837; these dates have not been accepted by previous authors; this work should be attributed to Potiez who was commenting on the Michaud collection bought by the Douai Museum].

Potiez V.L.V., 1844. Gallerie des mollusques, ou catalogue méthodique, descriptif et raisonné des mollusques et coquilles du Muséum de Douai. Paris: J.-B. Bailliére. [I-IV], [XXXVII]-XLIV, 1-308, [I-IV, errata]. [The second half of the Atlas with pagination of [I-IV], [57-80 pp.] containing pls. XXXVIII-LXX, may have been published with the 1844 volume; dates on individual plates are XXXVIII-XLIV, 1837; XLV-LVI, 1838; LVII-LXX, 1839; these dates have not been accepted by previous authors].

Puillandre N., Samadi S., Boisselier M.-C., Sysoev A.V., Kantor Y.I., Cruaud C., Couloux C. \& Bouchet P., 2008. Starting to unravel the toxoglossan knot: molecular phylogeny of the "turrids" (Neogastropoda: Conoidea). Molecular Phylogenetics and Evolution, 47: 1122-1134.

Pusateri F., Giannuzzi-Savelli R. \& Oliverio M., 2012. A revision of the Mediterranean Raphitomidae I: on the sibling species Raphitoma contigua Monterosato, 1884 and Raphitoma spadiana $\mathrm{n}$. sp. (Gastropoda, Conoidea). Iberus, 30: 41-52.
Pusateri F., Giannuzzi-Savelli R., Bartolini S. \& Oliverio M., 2017. A revision of the Mediterranean Raphitomidae (Neogastropoda, Conoidea) 4: The species of the group of Raphitoma purpurea (Montagu, 1803) with the description of a new species. Bollettino Malacologico, 53: 161-183.

Reeve L.A., 1843-1846. Monograph of the Genus Pleurotoma. Conchologia Iconica, or Illustrations of the Shells of Molluscous Animals. Reeve Brothers, London, Vol. 1, 40 pls. + index and errata. [Published in parts; I cite each part separately in the catalog as 1843b: pls. 1-18, published January-December, 1843; 1844a: pl. 19, published January, 1844; 1845: pls. 20-33, published October-December, 1845; 1846b: pls. $34-40$, index and errata, published January-April, 1846].

Taylor J.D., Kantor Y.I. \& Sysoev A.V., 1993. Foregut anatomy, feeding mechanisms, relationships and classification of Conoidea (Toxoglossa) (Gastropoda). Bulletin of the Natural History Museum, London (Zoology), 59: 125-170.

Tucker J.K., 2004. Catalog of Recent and fossil turrids (Mollusca: Gastropoda). Zootaxa, 682: 1-1295.

Tryon G.W., Jr., 1884. Conidae, Pleurotomidae. Manual of conchology, structural and systematic, with illustrations of the species. Philadelphia: Tryon. Vol. 6: 1-413; pls. 1-31 (Conidae); 1-34 (Pleurotomidae). [Pleurotomidae are in part 23: 151-214, pls. 1-13; and part 24: 215-413, pls. 14-34]. 
